\title{
Temporal variability of chlorophyll distribution in the Gulf of Mexico: bio-optical data from profiling floats
}

\author{
Orens Pasqueron de Fommervault ${ }^{1}$, Paula Perez-Brunius ${ }^{1}$, Pierre Damien ${ }^{1}$, Victor F. Camacho-Ibar ${ }^{2}$, and \\ Julio Sheinbaum ${ }^{1}$ \\ ${ }^{1}$ Departamento de Oceanografía Fisica, Centro de Investigación Científica y de Educación Superior de Ensenada, \\ Ensenada, 22860, Mexico \\ ${ }^{2}$ Instituto de Investigaciones Oceanológicas, Universidad Autónoma de Baja California Carretera Ensenada-Tijuana No. \\ 3917, Fraccionamiento Playitas, C.P. 22860, Ensenada, Baja California, Mexico
}

Correspondence: Orens Pasqueron de Fommervault (orens@ cicese.mx)

Received: 19 May 2017 - Discussion started: 6 June 2017

Revised: 30 October 2017 - Accepted: 3 November 2017 - Published: 15 December 2017

\begin{abstract}
Chlorophyll concentration is a key oceanic biogeochemical variable. In the Gulf of Mexico (GOM), its distribution, which is mainly obtained from satellite surface observations and scarce in situ experiments, is still poorly understood. In 2011-2012, eight profiling floats equipped with biogeochemical sensors were deployed for the first time in the GOM and generated an unprecedented dataset that significantly increased the number of chlorophyll vertical distribution measurements in the region. The analysis of these data, once calibrated, permits us to reconsider the spatial and temporal variability of the chlorophyll concentration in the water column. At a seasonal scale, results confirm the surface signal seen by satellites, presenting maximum concentrations in winter and low values in summer. It is shown that the deepening of the mixed layer is the primary factor triggering the chlorophyll surface increase in winter. In the GOM, a possible interpretation is that this surface increase corresponds to a biomass increase. However, the present dataset suggests that the basin-scale climatological surface increase in chlorophyll content results from a vertical redistribution of subsurface chlorophyll and/or photoacclimation processes, rather than a net increase of biomass. One plausible explanation for this is the decoupling between the mixed-layer depth and the deep nutrient reservoir since mixed-layer depth only reaches the nitracline in sporadic events in the observations. Float measurements also provide evidence that the depth and the magnitude of the deep chlorophyll maximum is strongly controlled by the mesoscale variability, with higher chlorophyll
\end{abstract}

biomass generally observed in cyclones rather than anticyclones.

\section{Introduction}

The Gulf of Mexico (GOM) is a semi-enclosed sea linked to the Caribbean Sea through the Yucatan Channel and to the Atlantic Ocean through the Florida Straits. It is characterized by a complex circulation dominated by the Loop Current (LC) that regularly forms large anticyclonic eddies ( 200-300 km diameter) that propagate westwards (e.g., Sturges and Leben, 2000). LC and LC eddies can be identified by Caribbean subtropical underwater (i.e., high salinity in the upper layer), and are clearly distinguishable from Gulf of Mexico common water, which is formed by vertical convective mixing within the gulf's uppermost $200 \mathrm{~m}$ in winter or by mixing induced by the collision of LC rings against the western gulf boundary (Elliott, 1982; Nowlin and McLellan, 1967; Vidal et al., 1992). Another important feature of the circulation in the GOM is the presence of relatively smaller cyclonic and anticyclonic eddies in many parts of the basin (e.g., Hamilton et al., 2002; Hamilton, 2007a; Schmitz, 2005).

From a biogeochemical point of view, the deep waters of the GOM are considered oligotrophic and nutrient limited, being relatively isolated from coastal eutrophic waters (Heileman and Rabalais, 2009). In deep water GOM, historical in situ measurements indicate low biological productivity 
$\left(<150 \mathrm{mgC} \mathrm{m}^{-2} \mathrm{~d}^{-1}\right)$ and low surface chlorophyll concentration (hereafter $[\mathrm{CHL}]_{\text {surf }}$ ) with values ranging from 0.06 to $0.32 \mathrm{mg} \mathrm{m}^{-3}$, and being 2-3 times higher in subsurface waters (Biggs and Ressler, 2001; El-Sayed, 1972; KoblenzMishke et al., 1970).

Other studies, mostly based on satellite surface chlorophyll measurements (Müller-Karger et al., 1991; SalmerónGarcía et al., 2011), or numerical simulations (Fennel et al., 2011; Walsh et al., 1989; Xue et al., 2013), suggest important seasonal variations. Lower $[\mathrm{CHL}]_{\text {surf }}$ values are observed from May to July and maximum values are found in winter from December to February. This cycle is considered to be primarily triggered by annual changes in ocean-atmosphere fluxes (Virmani and Weisberg, 2003), resulting in the deepening of the mixed layer in winter. In the GOM, it has been suggested that a higher $[\mathrm{CHL}]_{\text {surf }}$ in winter occurs concomitantly with a biomass increase, as a consequence of nutrient entrainment at the surface (Jolliff et al., 2008; Melo González et al., 2000; Müller-Karger et al., 1991, 2015; Salmerón-García et al., 2011). However, this has never been truly demonstrated due to the absence of sufficient data at the proper spatio-temporal scales in the water column. Furthermore, recent studies conducted in various oligotrophic environments, also suggest that [CHL] variability in the surface layer may primarily reflect changes in intracellular pigment concentration, rather than biomass variability (Behrenfeld et al., 2016; Halsey and Jones, 2015; Jakobsen and Markage, 2016; Siegel et al., 2013). Hence, the main processes involved in the seasonal variability of surface chlorophyll in the GOM have not yet been resolved.

Superimposed on the seasonal variability, several sporadic processes, such as mesoscale and submesoscale activity (Belabbassi et al., 2005; Biggs and Ressler, 2001; Linacre et al., 2015; Toner et al., 2003) or river run-off (Lohrenz et al., 1997; Nababan et al., 2011), may alter the [CHL] distribution in the deep GOM. These structures are hardly detectable from traditional in situ measurements (ship-based data rarely achieve the required spatio-temporal resolution), and their impact on the phytoplankton distribution and dynamics in the GOM remains to be established. The overall lack of data in the deep water GOM has, so far, produced a very limited picture of the [CHL] distribution, with low time and spatial resolution contributing to this uncertainty.

The development of autonomous Lagrangian platforms equipped with miniaturized bio-optical sensors now provides high-frequency and multiannual time series of physical and biogeochemical observations (Johnson et al., 2009). In the GOM, the pioneer work of Green et al. (2014) demonstrated the great potential of using profiling floats with bio-optical sensors and showed the complex [CHL] variability present in the deep GOM. Following this first successful attempt, and with the aim to monitor the water column of the entire GOM, seven other floats with bio-optical sensors (chlorophyll and CDOM fluorimeter, backscatterometer) and CTD were deployed in 2011 and 2012, as part of a project funded by the Bureau of Ocean Energy Management (BOEM, see Hamilton et al., 2016a). Each float obtained bi-monthly profiles over a total period of nearly 5 years inside the GOM.

In this study, we focus specifically on chlorophyll fluorescence (FLUO) measurements. For the first time in the GOM, we present high-frequency calibrated chlorophyll fluorescence time series using profiling floats, simultaneously acquired in different parts of the basin. The objective is to study the influence of physical forcing on the variability of the [CHL] vertical distribution. Of particular interest is its annual cycle, since it is the first time enough in situ measurements are available to resolve this temporal scale at depth, and explore to what extent the surface dynamics, as seen by satellite, is representative of the variability within the water column. We also investigate the [CHL] variability at shorter timescales and evaluate the role of mesoscale structures/water masses in shaping the annual cycle. This work provides a better understanding of the mechanisms controlling the distribution and the dynamics of phytoplankton in the deep GOM. Our analysis indicates that at a basin scale, the winter surface [CHL] maximum in the GOM may not necessarily be produced by a biomass increase, but would be associated with a vertical redistribution of subsurface chlorophyll and/or photoacclimation processes.

\section{Data and methods}

\subsection{APEX float database}

The float database is composed of eight APEX profiling floats (Teledyne-Webb Research, Inc.) deployed in the deep GOM. Two of them experienced technical issues (floats " 05 " and " 08 ") and were discarded from the dataset. The profiling floats had a rest depth of $1500 \mathrm{~m}$ and profiles were made every 14 days for most of the study. Data were transmitted in real-time using Iridium communication each time the float surfaced.

In addition to the standard conductivity-temperaturedepth (CTD) sensors mounted on typical Argo profiling floats (Roemmich et al., 2003), BOEM floats were also equipped with an ECO FLbbCD-AP2 sensor (WET Labs, Inc.). This sensor allowed the measurement of [CHL] and colored dissolved organic matter (CDOM) fluorescence, as well as the optical backscattering (bbp) at $700 \mathrm{~nm}$ (see Green et al., 2014 for more details). Bio-optical estimations were performed from 0 to $1500 \mathrm{~m}$ depth (about $5 \mathrm{~m}$ resolution in the $0-200 \mathrm{~m}$ layer, $10 \mathrm{~m}$ resolution in the $200-500 \mathrm{~m}$ layer, $20 \mathrm{~m}$ resolution in the remaining range).

Data were collected over a time period of approximately 5 years (2011 through 2015), and a total of 537 profiles of both physical and bio-optical parameters were acquired in the whole GOM Basin (Table 1). The resulting dataset has good spatial coverage (Fig. 1, left panel), and, on a monthly basis, all periods were sampled in an equivalent manner (Fig. 1, 
Table 1. Practical information about float mission and $\alpha$ and $\beta$ coefficients values used for the calibration of fluorescence profiles measured by APEX floats.

\begin{tabular}{lllllll}
\hline Float & 4902284_G4901600 & 4902285_G4901601 & 4902286_G4901602 & 4902289_G4901603 & 4902287_G4901604 & 4902290_G4901606 \\
\hline Start date & 20 Jul 2011 & 12 Jan 2012 & 16 Jan 2012 & 24 Jun 2012 & 11 Jul 2012 \\
End date & 18 Aug 2013 & 11 Nov 2015 & 18 Nov 2015 & 19 Nov 2015 & 21 Nov 2015 \\
Number of profiles & 83 & 99 & 99 & 88 & 12 Nov 2015 \\
$\alpha$ & 0.63 & 0.63 & 0.66 & 0.59 & 81 \\
$\beta$ & 0.030 & 0.050 & 0.039 & 0.026 & 0.60 \\
\hline
\end{tabular}

right panel). Hereafter, we focus our discussion on the [CHL] time series.

\subsection{Fluorescence profiles calibration}

The measurement of in vivo FLUO is widely used as a proxy for [CHL] (Lorenzen, 1966) which is, in turn, the main proxy for phytoplankton biomass (Cullen, 1982; Strickland, 1965). However, the conversion of FLUO into [CHL] must be done with great care. FLUO and [CHL] are generally considered proportional, which can be formalized as

$[\mathrm{CHL}]=\alpha \cdot(\mathrm{FLUO}-\beta)$,

where the $\alpha$ and $\beta$ coefficients (respectively instrumental gain and offset) are provided by the manufacturer. However, the values of these coefficients are rarely satisfactory and require post-processing evaluation (Boss et al., 2008; Guinet et al., 2013; Mignot et al., 2011; Xing et al., 2012). In addition, other biogeochemical processes, such as taxonomic composition and physiological acclimation mechanisms, are known to modulate the proportionality of FLUO and [CHL] (Cunningham et al., 1996; Falkowski and Kiefer, 1985; Kiefer, 1973), and must be taken into account for calibration purposes.

Among the physiological acclimation mechanisms affecting the FLUO-[CHL] relationship, the most serious issue is the non-photochemical quenching (NPQ) related to the decrease of the FLUO signal at the surface, in conditions of high light intensity (Cullen and Lewis, 1995). The first step of the calibration procedure is to provide a systematic correction of the NPQ. We applied the method of Xing et al. (2012), which is actually implemented in the international Biogeochemical-Argo program (Schmechtig et al., 2014). The method consists in finding, within the layer between the surface and 0.9 times the mixed-layer depth (MLD), the highest FLUO value $\left(\mathrm{FLUO}_{\max }\right)$ and its depth $\left(\mathrm{FLUO}_{z, \max }\right)$. $\mathrm{FLUO}_{\text {max }}$ is then extrapolated from $\mathrm{FLUO}_{z, \max }$ (considered as a proxy of the thickness of the layer potentially affected by the NPQ) up to the surface. For this specific purpose, FLUO profiles were smoothed, using a 5-point moving median filter, and the MLD was calculated from density profiles, using a $0.03 \mathrm{~kg} \mathrm{~m}^{-3}$ density criterion (de Boyer Montegut et al., 2004). The relevance of this NPQ correction in oligotrophic areas was specifically addressed in Lavigne et al. (2012), which showed it has a positive and significant impact on the estimates of chlorophyll.

The second step of the procedure is to correct FLUO profiles from instrumental offset. For each profile, the mean value at depth (i.e., deeper than $500 \mathrm{~m}$ ), was then computed $\left(\mathrm{FLUO}_{\text {deep }}\right)$. Assuming [CHL] is zero below $500 \mathrm{~m}$, $\beta$ (which indicates the response of the instrument in the absence of signal) was then determined as the median value of FLUO $_{\text {deep }}$ (Table 1).

The third step of the procedure is to evaluate the $\alpha$ parameter. This was performed following the method of Lavigne et al. (2012) and using ocean color satellite measurements (8-day composite images at $4 \mathrm{~km}$ spatial resolution from the Aqua MODIS satellite ocean color sensor, OCx Algorithm, available on https://oceancolor.gsfc.nasa.gov/cgi/l3). Float and satellite data were matched-up considering 8-day time intervals and $\pm 0.25^{\circ}$ spatial windows centered on the geographical position of the float profile. Corresponding satellite [CHL] values were extracted and averaged. The match-up was taken into account in the calibration procedure if at least $30 \%$ of satellite values were available. The number of valid match-ups was $60,74,67,75,82$, and $74 \%$ for floats " 00 ", "01", "02", "03", "04", and "06", respectively. The integrated chlorophyll content over 1.5 times the euphotic depth was then estimated from satellite [CHL] using empirical relationships (Uitz et al., 2006) and compared to the corresponding FLUO value (previously corrected for offset and NPQ). For the comparison, the whole 1.5 euphotic layer was used instead of only surface records to minimize the error that would be induced by a wrong NPQ parameterization. Finally, for a given float, $\alpha$ was calculated as the median value of the multiplicative coefficients obtained by the match-up (Table 1).

Although this method was not directly validated in the GOM, a comparison between satellite-calibrated profiles and in situ HPLC [CHL] data was performed by Lavigne et al. (2012) at the station BATS $\left(32^{\circ} \mathrm{N}\right.$ and $64^{\circ} \mathrm{W}$, in the Sargasso Sea). It was shown that calibrated profiles were unbiased with an associated median error of $29 \%$, which is reduced to $16 \%$ when climatological averages are compared. These values may be reasonably applied to the GOM, considering that the vertical distribution of the [CHL] at BATS is relatively close to what is observed in the GOM (Michaels and Knap, 1996). 

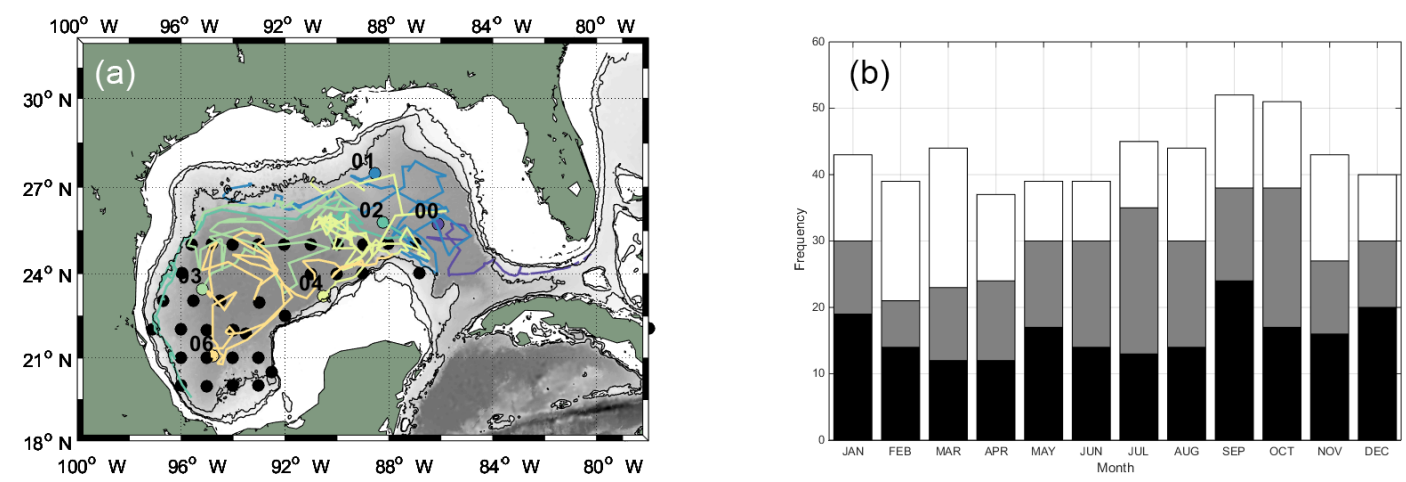

Figure 1. (a) Map of the study area, with tracks of BOEM floats (colored lines), and XIXIMI-2 and XIXIMI-3 sampling stations (black circles). Float positions at deployment are indicated by colored circles and numbers. (b) Temporal distribution of the profiles acquired by the BOEM (in black, cyclonic group profiles; in gray, anticyclonic group profiles; in white, remaining profiles).

\subsection{Particle backscattering profiles}

Profiles of particulate backscattering coefficient at $700 \mathrm{~nm}$ (bbp, in $\mathrm{m}^{-1}$ ) were obtained following the Green et al. (2014) protocol, and using the laboratory calibrations. High-frequency spikes were further removed from the bbp data by applying successively a 5 -point running median filter and 7-point mean filter spikes (Briggs et al., 2011).

In our study, the bbp that is to first order correlated to the chlorophyll concentration (Huot et al., 2008; Loisel and Morel, 1998; Morel and Maritorena, 2001), was used as an alternative measure of the phytoplankton carbon biomass (e.g., Behrenfeld et al., 2005; Westberry et al., 2010). The [CHL]-bbp relationship is however known to be altered by physiological variations (Antoine et al., 2011; Behrenfeld and Boss, 2003), in particular because the CHL signal is strongly impacted by changes in intracellular pigment concentration resulting from photoacclimation (Fennel and Boss, 2003; Kitchen and Zaneveld, 1990; Mitchell and Kiefer, 1988). Hence, in this work, we also considered the ratio bbp / [CHL] as a proxy of phytoplankton carbon biomass to CHL and used it to track changes in phytoplankton photoacclimation processes (Behrenfeld and Boss, 2003, 2006; Mignot et al., 2014). It is worth noting that in the absence of published empirical conversion factors in the GOM, bbp data were not converted to a carbon equivalent. We therefore considered qualitatively bbp, and used them primarily to assist in the interpretation of [CHL] profiles.

\subsection{Nutrient data}

In the present study we also used nutrients (more precisely nitrate + nitrite concentrations, hereafter $[\mathrm{NN}])$ from bottle measurements acquired during the XIXIMI-2 (July 2011) and XIXIMI-3 (February-March 2013) cruises. More than 900 water samples were acquired from 74 profiles in the deep water region of the southern GOM (25 to $20^{\circ} \mathrm{N}$ and 87 to $95^{\circ} \mathrm{W}$; Fig. 1, left panel). Nutrient analyses were performed with a Skalar SANplus segmented-flow nutrient analyzer according to the protocols described in Gordon et al. (1993), and $[\mathrm{NN}]$ were determined according to a modification of the Armstrong et al. (1967) procedure.

\subsection{Detection of mesoscale structures}

In the present study, mesoscale structures were characterized according to the vertical distribution of temperature, considering that isotherms are generally displaced downward (upward) in anticyclonic (cyclonic) structures in comparison with the background field (McGillicuddy and Robinson, 1997). The objective was to see if biological patterns could be identified in response to different physical situations. The classification of the mesoscale structures (which, in the GOM, encompass eddies but also structures that are part of the mean circulation such as LC and LC eddies), was carried out using the depth of the $6^{\circ} \mathrm{C}$ isotherm (hereafter T6) for the following reasons:

- The GOM can be studied as a two-layer baroclinic system, with vertical displacements of the 6 to $10^{\circ} \mathrm{C}$ isotherms (located at the base of the LC and LC eddies and at $400-600 \mathrm{~m}$ depth in cyclonic eddies) being anticorrelated with sea surface height (Donohue et al., 2007 and 2008; Hamilton, 2007b, 2016a, b; Sheinbaum et al., 2007).

- T6 is in the lower thermocline and has been used as the interface for a two-layer system, separating deep waters from the more energetic upper layer containing mesoscale structures and the LC (Bunge et al., 2002; Donohue et al., 2008; Hamilton et al., 2016a, b).

- T6 is directly measured by the profiling floats.

BOEM float profiles were thus gathered in different clusters according to the depth of T6, and, for statistical reasons, criteria were chosen symmetrical to the mean T6 depth 
(a)

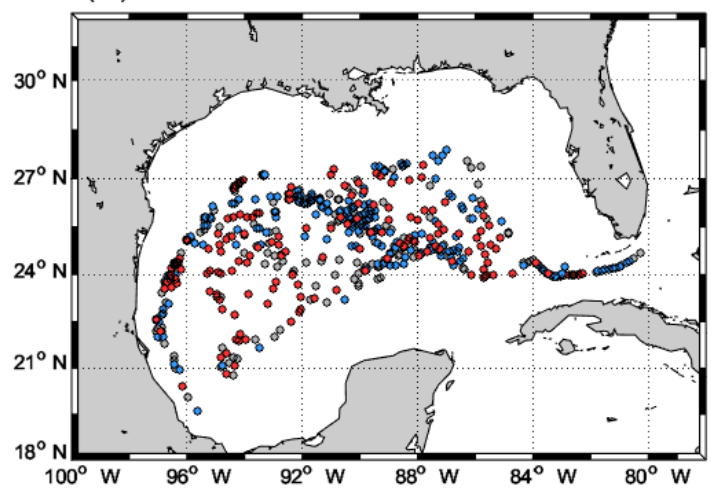

(b)

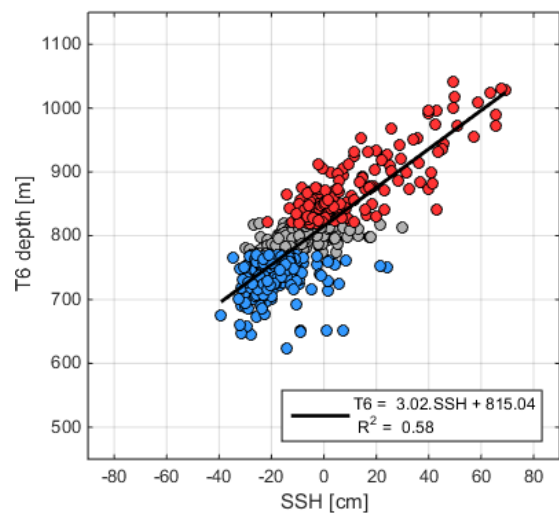

(c)

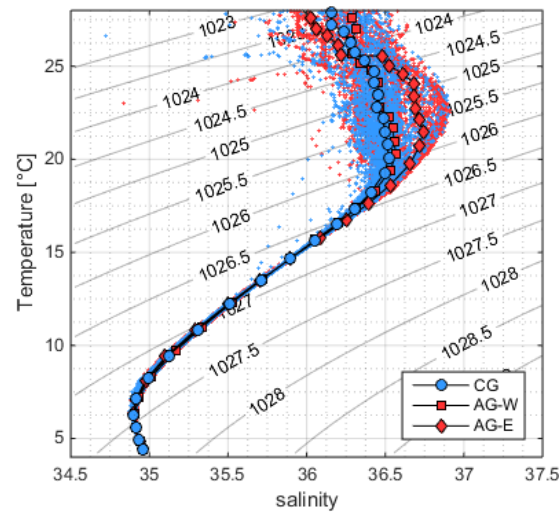

Figure 2. (a) Position of float profiles. Depth of the $6^{\circ} \mathrm{C}$ isotherm derived cyclones and anticyclones are given by blue and red circles respectively. (b) Depth of the $6^{\circ} \mathrm{C}$ isotherm versus SSH (gridded data with a spatial resolution of $1 / 8^{\circ}$, produced by Ssalto/Duacs and distributed by AVISO, with support from CNES (http://www.aviso.altimetry.fr/duacs). To remove seasonal steric effects of large-scale heating and cooling of the upper water column, daily mean SSH calculated in the Gulf of Mexico were systematically subtracted from SSH values. Blue points correspond to the cyclonic group, and red points to the anticyclonic group. (c) T/S diagram. Cyclones are identified in blue (blue circles are mean values) and anticyclones in red (red squares are profiles acquired at a latitude west of $-88^{\circ}$ (west GOM) and red diamonds are profiles acquired at a latitude east of $-88^{\circ}$ (east GOM).

to obtain groups of equivalent size. From here on, the cyclonic group (CG) will correspond to profiles with shallowest T6 $(<770 \mathrm{~m})$ and the anticyclonic group (AG) to profiles of deepest $\mathrm{T} 6(>820 \mathrm{~m})$, with the remaining profiles (i.e., $770 \mathrm{~m}>\mathrm{T} 6>820 \mathrm{~m}$ ) considered undefined or neutral. Even though T6 is not very sensitive to seasonal variability, profiles are homogeneously distributed within each group. That is, all seasons are equally sampled on average, with 14 profiles available per group and per month (Fig. 1, right panel). The spatial distribution of cyclones and anticyclones resulting from the T6 depth analysis are given in Fig. 2 (top panel).

A T-S diagram using all the profiles (Fig. 2, bottom right panel) shows that most cyclones have GOM common water (uniform salinity of $\sim 36.5$ between the 1024.5 and $1025.6 \mathrm{~kg} \mathrm{~m}^{-3}$ isopycnal levels) while the anticyclones are more mixed. Eastern structures have a clear Caribbean subtropical underwater signal (warm and salty water at the struc- ture's core, red diamonds in Fig. 2) whereas western structures tend towards GOM common water (red squares). In that sense, this classification also characterizes profiles in terms of water mass properties.

The relationship between T6 and sea surface height (SSH) obtained from altimetry, which is more conventionally used for the identification of eddies in the GOM (e.g., Leben and Born, 1993), was examined in our dataset. T6 was plotted against SSH at the location and time of the profile (left bottom panel in Fig. 2, see legend for SSH calculation details). Results reveal a good and positive correlation between T6 and SSH values $\left(R^{2}=0.58\right)$ and confirms the results of Hamilton et al. (2016a), obtained from a larger dataset (i.e., maximum SSH values in anticyclones and minimum values in cyclones). This also suggests that the depth of T6 is a good proxy to classify profiles from a mesoscale perspective in the GOM. The ability of the method to identify mesoscale fea- 

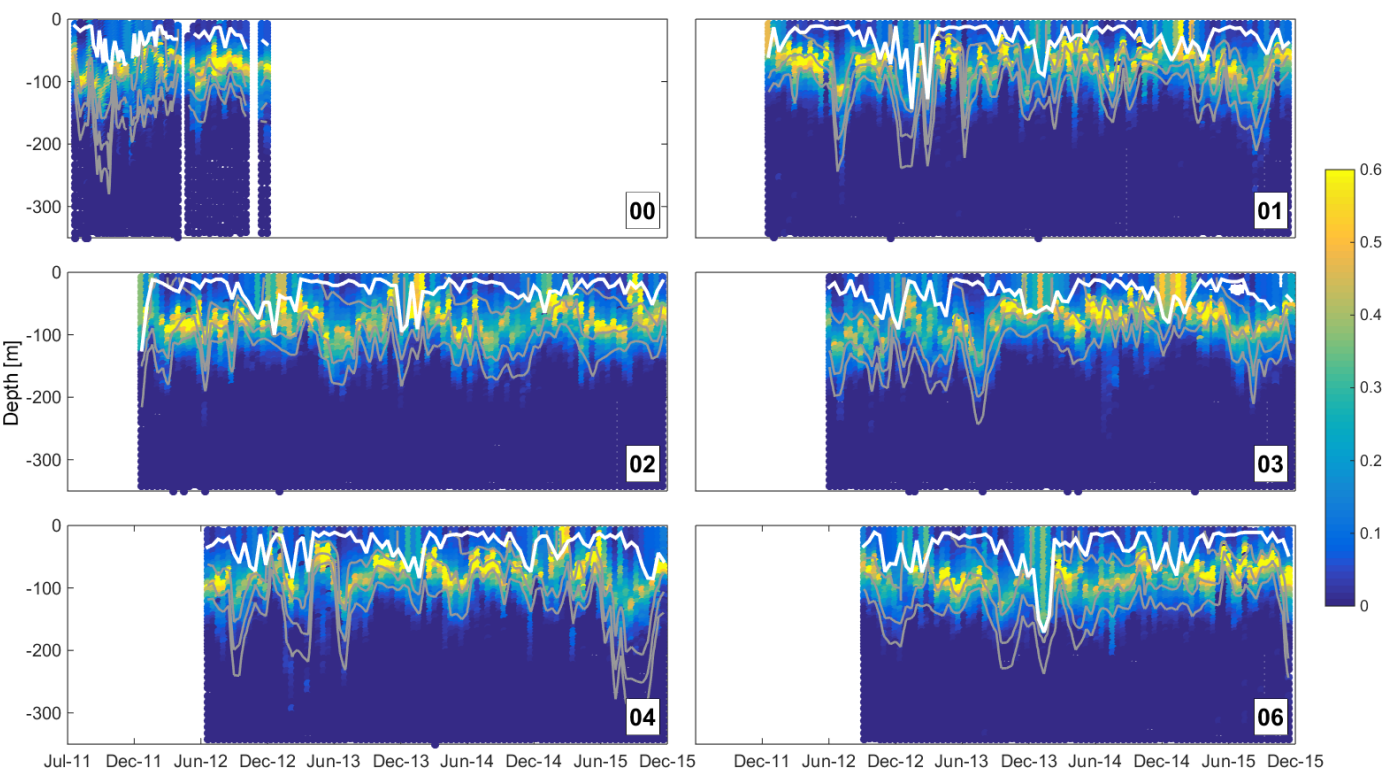

Figure 3. Calibrated [CHL] float transects in $\mathrm{mg} \mathrm{m}^{-3}$. Contour plots of density (1024.5 $1025.51026 \mathrm{~kg} \mathrm{~m}^{-3}$, gray lines), and mixed-layer depth calculated as the depth where the difference of density from the surface reference, fixed at $10 \mathrm{~m}$-depth, is $0.03 \mathrm{~kg} \mathrm{~m}{ }^{-3}$ (solid white line), are superimposed.

tures was verified by comparing results with those obtained using an SSH criterion, which yield only a minor difference (Supplement Fig. S1).

\section{Results and discussion}

\subsection{Seasonal cycle}

During the 5 years of observation, the BOEM floats provided a repeated coverage of the deep GOM. The MLD, generally considered to be the main physical factor influencing upperlayer phytoplankton dynamics and chlorophyll concentration ([CHL]; e.g., Mann and Lazier, 2006), show consistent seasonal patterns (Figs. 3 and 4).

Regarding the MLD, in summer (i.e., from June to $\mathrm{Au}$ gust) shallow values are measured (mean value $=18 \pm 8 \mathrm{~m}$ ) as an indication of a well-stratified water column. In autumn (September-October) a deepening of the mixed layer is observed, with a mean value of $37 \pm 19 \mathrm{~m}$. Relative maximum values are reached in winter from December to February (mean value of $50 \pm 30 \mathrm{~m}$ ), and this period is also characterized by a strong scattering of the values in which MLD deeper than $80 \mathrm{~m}$ are not uncommon. Maximum MLD are present in the float " 01 " time series in winter 2012/2013 and float "06" time series in winter 2013/2014 (Figs. 3 and 4). During these periods, maximum MLD can reach more than $150 \mathrm{~m}$. In spring (from March to May), there is a gradual increase of surface density, leading to a progressive stratification of the water column and the mixed layer becomes thinner (Figs. 3 and 4).
Concerning [CHL], large variability is observed above $200 \mathrm{~m}$ in all time series. Overall, a deep chlorophyll maximum (DCM), characteristic of an oligotrophic environment, is detected at around $70-100 \mathrm{~m}$ depth throughout the year, although this feature tends to disappear in winter (Fig. 3, Table 2). At a seasonal scale, $[\mathrm{CHL}]_{\text {surf }}$ here calculated as the mean [CHL] in the $0-30 \mathrm{~m}$ layer, exhibits a clear pattern despite the strong spatial and inter-annual variability produced by mixed-layer dynamics (Fig. 4). In summer, when the MLD is minimum, $[\mathrm{CHL}]_{\text {surf }}$ is very low, and generally under $0.1 \mathrm{mg} \mathrm{m}^{-3}$ (Fig. 4). During this season the MLD is occasionally found deeper than the top of the DCM (defined as the first depth where $[\mathrm{CHL}]_{\text {surf }}$ exceeds $0.1 \mathrm{mg} \mathrm{m}^{-3}$, i.e., 4 times the detection limit of the sensor), but such events are very rare $\left(11 \%\right.$ of the profiles). In autumn, the mean $[\mathrm{CHL}]_{\text {surf }}$ remains low $\left(0.09 \mathrm{mg} \mathrm{m}^{-3}\right)$ although slightly higher than the concentration measured in summer. The MLD reaches the top of the DCM in around $40 \%$ of the autumn profiles. Maximum values of $[\mathrm{CHL}]_{\text {surf }}$ are observed in winter (mean value of $0.22 \mathrm{mg} \mathrm{m}^{-3}$ ) when the MLD is generally the deepest. During this season, the MLD shows large variability and generally reaches the DCM ( $~ 80 \%$ of the winter profiles), which results in large dispersion of the measured $[\mathrm{CHL}]_{\text {surf }}$ values (Fig. 4). In spring, $[\mathrm{CHL}]_{\text {surf }}$ decreases (mean values of $0.09 \mathrm{mg} \mathrm{m}^{-3}$ ), and a MLD deeper than the top of the DCM is only observed in $26 \%$ of the profiles. The seasonal cycle of the $[\mathrm{CHL}]_{\text {surf }}$ obtained from the float profiles is consistent with that reported using satellite measurements (MüllerKarger et al., 1991; Salmerón-García et al., 2011).

If the integrated content of CHL over the $0-350 \mathrm{~m}$ layer $\left([\mathrm{CHL}]_{\text {tot }}\right)$ is now examined, interestingly, no clear seasonal 

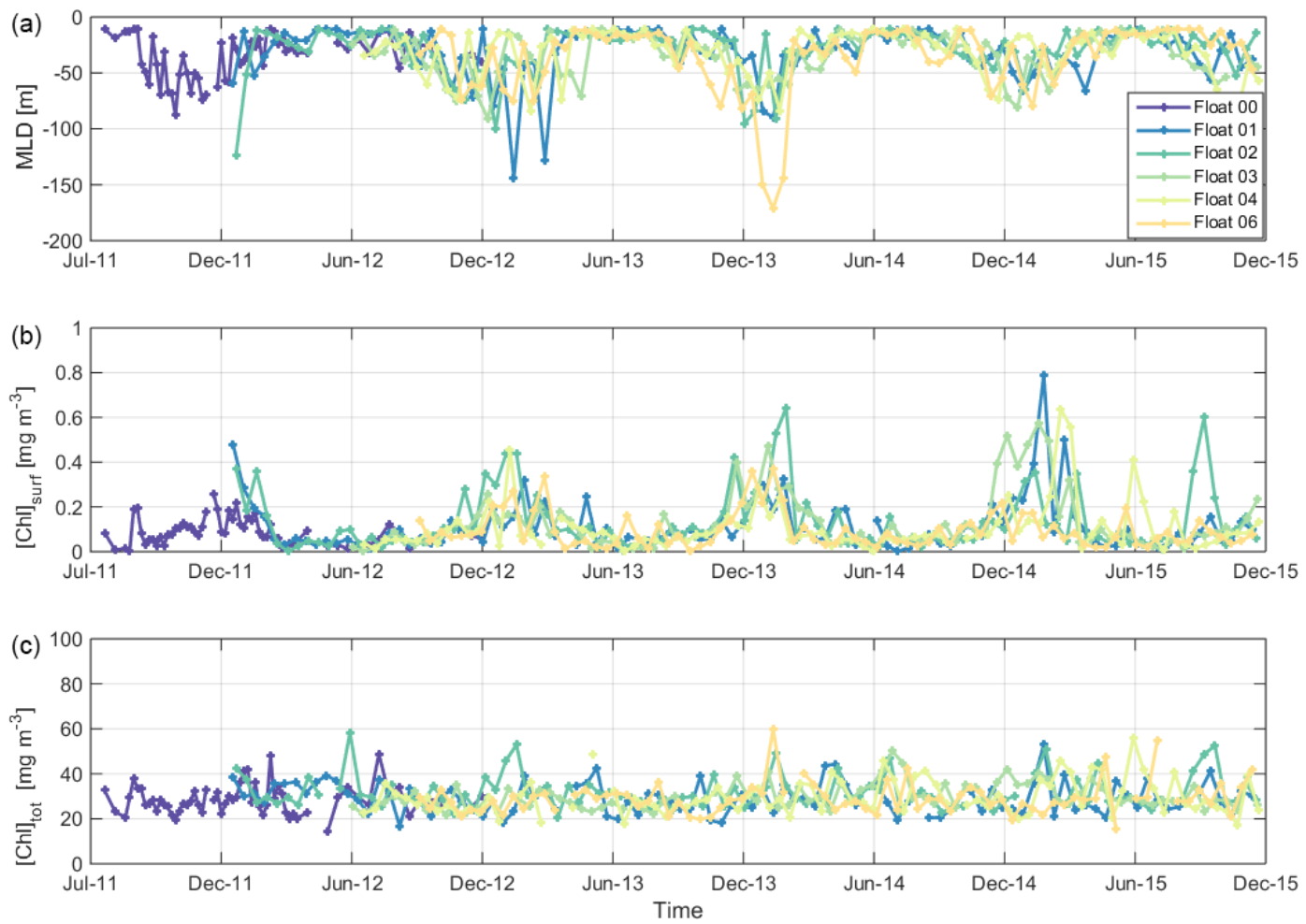

Figure 4. Float time series of the (a) mixed-layer depth, (b) mean surface chlorophyll concentration, and (c) integrated content of chlorophyll over the $0-350 \mathrm{~m}$ layer.

variability is observed, or at least, its spatial and/or interannual variability is higher. [CHL] tot remains almost constant all along the seasons, with a mean value around $30 \mathrm{mg} \mathrm{m}^{-2}$ (Fig. 4). In other words, the winter increase in $[\mathrm{CHL}]_{\text {surf }}$ is not mirrored by the $[\mathrm{CHL}]_{\text {tot }}$. This is a noteworthy result, given that the seasonal cycle of the [CHL] in the GOM, at a basin scale, has been almost exclusively addressed using satellite observations, which only provide surface information. Having said that, one may wonder how much of the phytoplankton chlorophyll variability is reflective of true changes in total biomass in the entire water column. Indeed, it is well known that the [CHL] is not a sole function of phytoplankton biomass and depends on several other factors, such as photoacclimation processes (e.g., Geider, 1987). In our study, this question was addressed by considering particulate backscattering measurements (bbp) performed by the floats, which could be viewed as an alternative and independent estimate of phytoplankton carbon biomass (Behrenfeld and Boss, 2003). Results presented in the Supplement (Fig. S2) show no increase of bbp in winter in either surface mean or vertically integrated values. This seems to confirm that, at a seasonal scale, the total phytoplankton biomass (i.e., integrated over the $0-350 \mathrm{~m}$ layer) would remain relatively stable in deep water GOM, and that the surface increase in $[\mathrm{CHL}]_{\text {surf }}$ might not reflect an increase in phytoplankton biomass.
Having said that, different mechanisms could explain this result. In a two-layer approach - i.e., considering separately the upper part of the photic layer (a priori nutrient limited and light limited only in winter) and the lower part (a priori light limited but less nutrient starved) - the $[\mathrm{CHL}]_{\text {surf }}$ increase, without a similar trend in the bbp signal (Fig. S2), would be the result of photoacclimation processes (Mignot et al., 2014). The underlying assumption is that during the winter period, the average light intensity for phytoplankton is reduced in the mixed layer with respect to summer conditions leading to an increase in intracellular chlorophyll content. This scenario seems reasonable to explain the winter $[\mathrm{CHL}]_{\text {surf }}$ increase but becomes on its own questionable if we take into account that $[\mathrm{CHL}]_{\text {tot }}$ remains constant at a seasonal scale. Another mechanism to explain the distribution of the $[\mathrm{CHL}]$ in winter would be a vertical redistribution of the phytoplankton over the water column (Mayot et al., 2017). Low-light acclimated cells from the DCM would be transported to the surface by mixing process, and vice versa. This could be the case in the GOM, given that the mixed layer is generally deep enough to reach the DCM in winter $(\sim 80 \%$ of the profiles), thus connecting the upper and the lower part of the euphotic zone. Considering only the pure stirring of the DCM into the mixed layer assumes that phytoplankton cells do not have time to re-acclimatize to their new light environment (hours to days processes). So it is not warranted to test 
this hypothesis, given the temporal resolution of our floats (two profiles per month from each float). In situ observations by Qian et al. (2003) also suggested shifts in the surface phytoplankton community that could also account for changes in $[\mathrm{CHL}]_{\text {surf. }}$.

All these mechanisms are not necessarily exclusive and could even act together to explain the observed [CHL] seasonal cycle. In any case, relatively stable vertically integrated chlorophyll (and bbp) values indicate a constant phytoplankton biomass in the water column throughout the year. This would also imply that the mixed layer in winter, although sufficiently deep to reach the DCM, would be, nonetheless, insufficient for raising large quantities of nutrients and supporting a significant net increase in phytoplankton biomass. This contrasts with conclusions from previous studies conducted in the GOM that suggest an increase of biomass in winter based on surface information from chlorophyll satellite observations (Jolliff et al., 2008; Melo González et al., 2000; Müller-Karger et al., 1991, 2015; Salmerón-García et al., 2011) and will be further discussed in Sect. 3.3.

\subsection{Impact of mesoscale structures on the annual cycle}

Superimposed onto a seasonal signal, float profiles also show chlorophyll variability that occurs at shorter timescales. Subsurface temporal changes in [CHL] are closely related to isopycnals (black lines, Fig. 3), and the vertical displacement of the DCM is highly coherent with density. When profiles for which the MLD reaches the DCM are excluded (i.e., when the DCM structure is eroded), depth variations of the subsurface DCM are correlated with the vertical displacement of the nearby $1025.5 \mathrm{~kg} \mathrm{~m}^{-3}$ isopycnal $\left(R^{2}=0.57\right)$. Since the $1025.5 \mathrm{~kg} \mathrm{~m}^{-3}$ isopycnal is also correlated with $\mathrm{T} 6$ $\left(R^{2}=0.48\right)$, we observed that DCM is, on average, deeper in the anticyclonic group (AG) than in the cyclonic group (CG), whatever the time period (Table 2). Besides, a Student $t$ test confirms that the difference in DCM mean depth observed between the two groups is statistically significant independent of season (level of significance $p=0.05$ ). This variability overlaps with the seasonal deepening and shallowing of the DCM, characterized by deepest values in summer $(82 \pm 18 \mathrm{~m}$ in $\mathrm{CG}$ and $105 \pm 17 \mathrm{~m}$ in $\mathrm{AG})$ and shallowest values in winter $(68 \pm 19 \mathrm{~m}$ in CG and $75 \pm 11 \mathrm{~m}$ in $\mathrm{AG})$.

It is well known that the seasonal cycle of geophysical and biogeochemical variables is not monochromatic and has timescales that overlap those of mesoscale turbulence (e.g., Penduff et al., 2004). Thus, it is not possible to separate them properly. Although there is certainly seasonal variability in the GOM related to atmospheric forcing (air-sea fluxes and river run-off), spectra show comparable or more energetic variations related to the mesoscale in a band of frequencies that overlaps with seasonal variations (3-4 months for sea surface height, e.g., Hamilton and Lee, 2005; Jouanno et al., 2016). Hence, it could be expected that the variability observed at a given period of the year also depends on
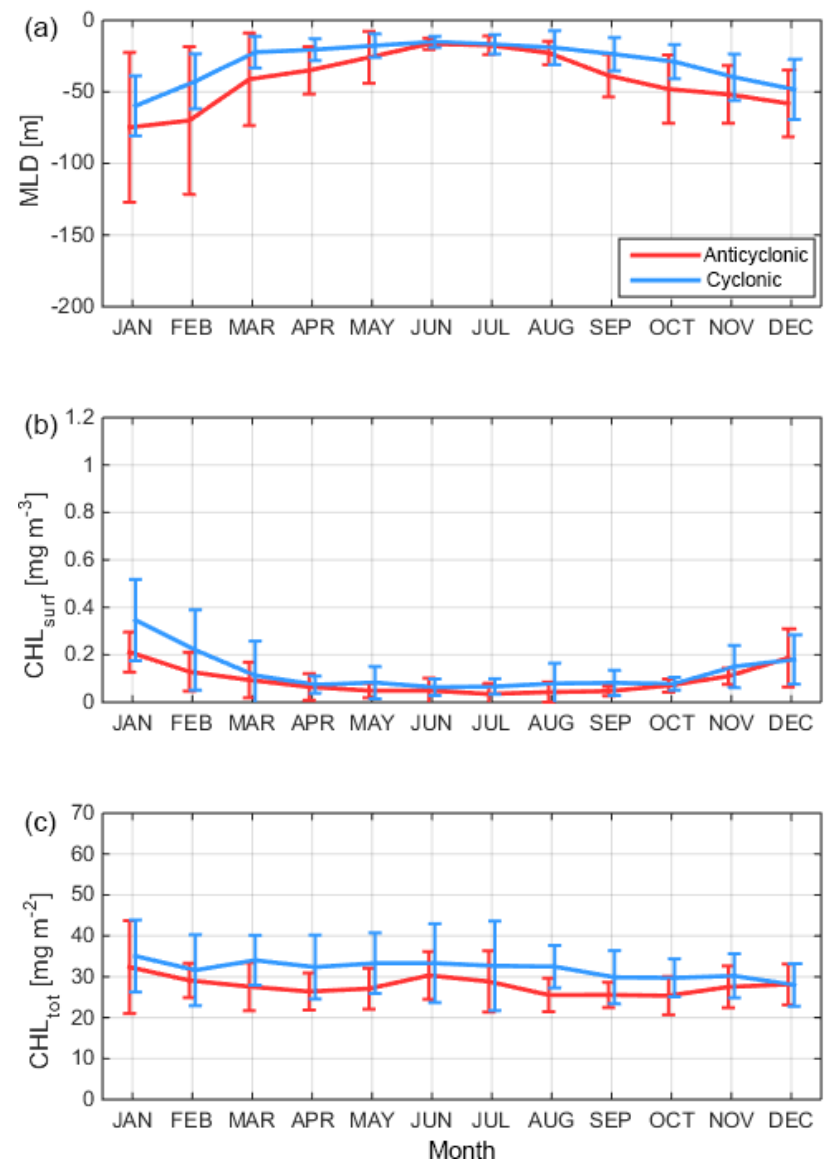

Figure 5. Basin-scale, monthly climatological mean and standard deviation of: (a) the mixed-layer depth, (b) surface chlorophyll and (c) integrated chlorophyll over the first $350 \mathrm{~m}$. Red (blue) shows statistics for all profiles in anticyclonic (cyclonic) structures.

the presence of mesoscale structures. We therefore analyzed the seasonal cycle, gathering data on a monthly basis, and considering separately profiles acquired in cyclonic and anticyclonic structures, to assess MLD and [CHL] ([CHL] $]_{\text {surf }}$ and $[\mathrm{CHL}]_{\text {tot }}$ ) differences between the two groups. Figure 5 shows that the climatological basin-scale averaged MLD is generally deeper in AG than in CG, as expected (Dufois et al., 2014; Kouketsu et al., 2012), although this difference is most often not significant ( $p<0.05$, except in April, September, and October) due to the strong dispersion in MLD measurements. The maximum difference is observed in January and February, with mean values around $70 \mathrm{~m}$ in AG and $50 \mathrm{~m}$ in CG (Fig. 5). In both groups, maximum climatological monthly values of $[\mathrm{CHL}]_{\text {surf }}$ are also observed in January and February (Fig. 5). A higher increase in $[\mathrm{CHL}]_{\text {surf }}$ is however observed in CG (only statistically significant in February), even though the mean MLD is shallower than in AG (mean $[\mathrm{CHL}]_{\text {surf }}$ for those months range around $0.2-0.1 \mathrm{mg} \mathrm{m}^{-3}$ for AG and $0.3-0.2 \mathrm{mg} \mathrm{m}^{-3}$ for $\mathrm{CG}$ ). 
Table 2. Seasonal mean and standard deviation of the phytoplankton maximum $\left(\mathrm{DCM}_{\mathrm{max}}\right.$, in $\left.\mathrm{mg} \mathrm{m}^{-3}\right)$ and the depth of the phytoplankton maximum $\left(\mathrm{DCM}_{Z}\right.$, in meters). Values were obtained by considering only profiles for which the MLD is shallower than the DCM.

\begin{tabular}{llrrrr}
\hline & & Dec-Feb & Mar-May & Jun-Aug & Sep-Nov \\
\hline \multirow{2}{*}{ All } & $\mathrm{DCM}_{\max }$ & $0.54 \pm 0.13$ & $0.74 \pm 0.23$ & $0.64 \pm 0.25$ & $0.62 \pm 0.27$ \\
\cline { 2 - 6 } & $\mathrm{DCM}_{Z}$ & $69 \pm 17$ & $75 \pm 19$ & $91 \pm 21$ & $82 \pm 24$ \\
\hline \multirow{2}{*}{ Cyclonic } & $\mathrm{DCM}_{\max }$ & $0.53 \pm 0.14$ & $0.80 \pm 0.23$ & $0.73 \pm 0.28$ & $0.70 \pm 0.29$ \\
\cline { 2 - 6 } & $\mathrm{DCM}_{Z}$ & $68 \pm 19$ & $69 \pm 17$ & $82 \pm 19$ & $74 \pm 20$ \\
\hline \multirow{2}{*}{ Anticyclonic } & $\mathrm{DCM}_{\max }$ & $0.55 \pm 0.08$ & $0.60 \pm 0.18$ & $0.53 \pm 0.14$ & $0.45 \pm 0.12$ \\
\cline { 2 - 6 } & $\mathrm{DCM}_{Z}$ & $75 \pm 11$ & $91 \pm 15$ & $105 \pm 17$ & $100 \pm 22$ \\
\hline
\end{tabular}

Consistent with the results of Sect. 3.1, [CHL] tot shows no clear winter increase in either group (Fig. 5). By contrast, statistically significant differences $(p<0.05)$ between CG and AG are found from March to October, when the MLD is shallower. The monthly climatological mean $[\mathrm{CHL}]_{\text {tot }}$ is higher, on average, in $\mathrm{CG}\left(\sim 32 \mathrm{mg} \mathrm{m}^{-2}\right)$ than in $\mathrm{AG}$ $\left(\sim 28 \mathrm{mg} \mathrm{m}^{-2}\right)$, which is most likely related to an intensification of the DCM in CG (level of significance $p=0.05$, Table 2). Since the DCM is found significantly deeper in AG than in $\mathrm{CG}$, one might expect that differences in $[\mathrm{CHL}]_{\text {tot }}$ may not be reflective of changes in phytoplankton biomass, but may result from changes in environmental conditions (e.g., light) and a consequent modification of the ratio of CHL to phytoplankton carbon biomass. However, bbp vertical profiles suggest that the increase of $[\mathrm{CHL}]_{\text {tot }}$ in $\mathrm{CG}$ is also related to carbon biomass enhancement. Indeed, a higher bbp signal is observed in CG compared to AG (Supplement Fig. S3). In addition, in the DCM, the ratio bbp / CHL (proxy of phytoplankton carbon biomass to CHL), which tracks changes in phytoplankton physiology (Behrenfeld and Boss, 2003, 2006; Mignot et al., 2014), is very similar between the two groups (Supplement Fig. S3). Thus, it can be reasonably assumed that the CHL difference between CG and AG in the lower euphotic zone results from biomass variations and not from photoacclimation processes. As a consequence, in the GOM, the phytoplankton biomass may be more enhanced in cyclones than in anticyclones. The results agree with the negative correlation between $\mathrm{SSH}$ and $[\mathrm{CHL}]_{\text {surf }}$ anomaly found by Gaube et al. (2014) within the GOM - suggesting higher [CHL] concentrations in cyclones.

\subsection{Underlying processes: nutrient supply to the surface layer}

\subsubsection{Estimations of nutrient concentrations}

To better understand the possible mechanisms that explain the differences observed in the [CHL] field within the seasons and the two groups, we address here the role of nutrients (here nitrate + nitrite, $[\mathrm{NN}])$. In the absence of direct measurements, the vertical distribution of $[\mathrm{NN}]$ along float trajectories was estimated using XIXIMI-2 and XIXIMI-3 data. The objective was to infer the $[\mathrm{NN}]$ from float density profiles. Indeed, when $[\mathrm{NN}]$ are plotted against density (Fig. 6), three different layers can be distinguished: the surface layer where $[\mathrm{NN}]$ are exhausted, the intermediate layer where $[\mathrm{NN}]$ almost linearly increases with density, and the deep layer within which [NN] are decreasing. In the intermediate layer, which corresponds roughly to the pycnocline and the nitracline (black points on Fig. 6), we estimated the nitracline depth $\left(Z_{\mathrm{N}}\right)$ and the nitracline steepness $\left(S_{\mathrm{N}}\right)$ from linear regression $\left(R^{2}=0.91\right)$. Upper and lower limits of the intermediate layer (respectively 1025.5 and $1027.4 \mathrm{~kg} \mathrm{~m}^{-3}$ ) were chosen according to density criteria (since our goal was to infer the $[\mathrm{NN}]$ from float density profiles), and in order to minimize the error of the linear regression of $[\mathrm{NN}]$ versus density. In this way, the intermediate layer extends from the $[\mathrm{NN}]$ depleted layer to the $[\mathrm{NN}]$ maximum.

The linear fit to the $[\mathrm{NN}]$ versus density data (red line in Fig. 6) is

$[\mathrm{NN}]=16.58( \pm 0.59) \sigma_{\theta}-422.93( \pm 15.69)$,

where $\sigma_{\theta}$ is the potential density anomaly (the numbers in parentheses are the $95 \%$ confidence intervals). According to Omand and Mahadevan (2015), we can then find the $[\mathrm{NN}]$ depletion density $\sigma_{\theta}(0)$, where [NN] goes to zero as $\sigma_{\theta}(0)=422.93 / 16.58=25.5 \mathrm{~kg} \mathrm{~m}^{-3}$. Here $\sigma_{\theta}(0)$ represents the deepest isopycnal at which nitrate + nitrite is depleted (named also the nitrate depletion density; Kamykowski and Zentara, 1986). As a comparison, $Z_{\mathrm{N}}$ was compared to the nitracline depth estimated by Jolliff et al. (2008) using the $23.2{ }^{\circ} \mathrm{C}$ isotherm, with good agreement between the two methods $\left(R^{2}=0.96\right)$. $S_{\mathrm{N}}$ was also estimated, and can be deduced from Eq. (2):

$S_{\mathrm{N}}=\frac{\Delta\left[\mathrm{NO}_{3}\right]}{\Delta Z}=\frac{16.58 .\left(\sigma_{Z 2}-\sigma_{Z 1}\right)}{Z 2-Z 1}$.

Thus, by choosing $\sigma_{Z 2}$ and $\sigma_{Z 1}$ as the lower and upper limits of the intermediate layer (i.e., 1025.5 and $1027.4 \mathrm{~kg} \mathrm{~m}^{-3}$ ), $S_{\mathrm{N}}$ can be determined from float density profiles (Fig. 7). 


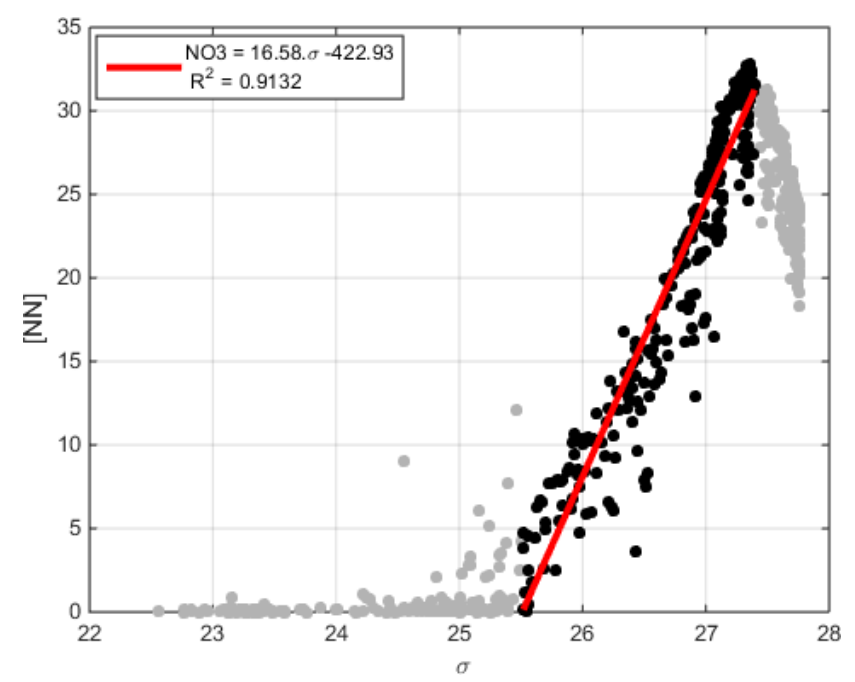

Figure 6. Nitrate + nitrite concentrations versus potential density anomaly data from XIXIMI-2 and XIXIMI-3 survey cruises. Measurements corresponding to the intermediate layer are plotted in black and were used for the determination of the linear fit (see text).

\subsubsection{Winter mixing}

In the deep water GOM, the deepening of the mixed layer in winter is assumed to carry cold and nutrient-rich subsurface water into the euphotic zone, in agreement with the annual cycle of the satellite surface chlorophyll (Jolliff et al., 2008; Müller-Karger et al., 1991). However, our analysis of the $[\mathrm{CHL}]$ over the whole water column suggests that the winter $[\mathrm{CHL}]_{\text {surf }}$ increase does not necessarily reflect a real increase in phytoplankton biomass resulting from new nutrient availability. This hypothesis is now tested by considering $[\mathrm{NN}]$ estimated from the float observations.

Figure 7, which represents the monthly climatological basin-scale mean and standard deviation of the nitracline depth and the nitracline steepness, shows that $Z_{\mathrm{N}}$ is always found at depth and does not show a clear seasonal pattern (regardless of the group). In addition, the climatological winter mixed layer is generally shallower than the nitracline (Fig. 5). Hence, if we assume that large inputs of nutrients can only be expected when the MLD reaches below the average nitracline depth $\left(Z_{\mathrm{N}}\right)$, it is likely that nutrients injections to the photic layer by vertical mixing are low on average, even in winter. A profile-to-profile comparison shows that, in our dataset, a MLD much deeper than the inferred $Z_{N}$ was observed only once (in an AG structure), on 23 January 2014. During this event, the MLD reached $171 \mathrm{~m}$ (Fig. 4, the maximum value measured by the floats), and the [CHL] tot reached more than $60 \mathrm{mg} \mathrm{m}^{-3}$ - i.e., twice the mean winter $[\mathrm{CHL}]_{\text {tot }}$ value (i.e., $0.22 \mathrm{mg} \mathrm{m}^{-3}$ ). Nutrients may not be measured at the surface as they are taken up by phytoplankton. However, the fact that we do not observe $\mathrm{NN}$ accumulation at the surface means that nutrient refuelling is relatively small or, in some way, slower
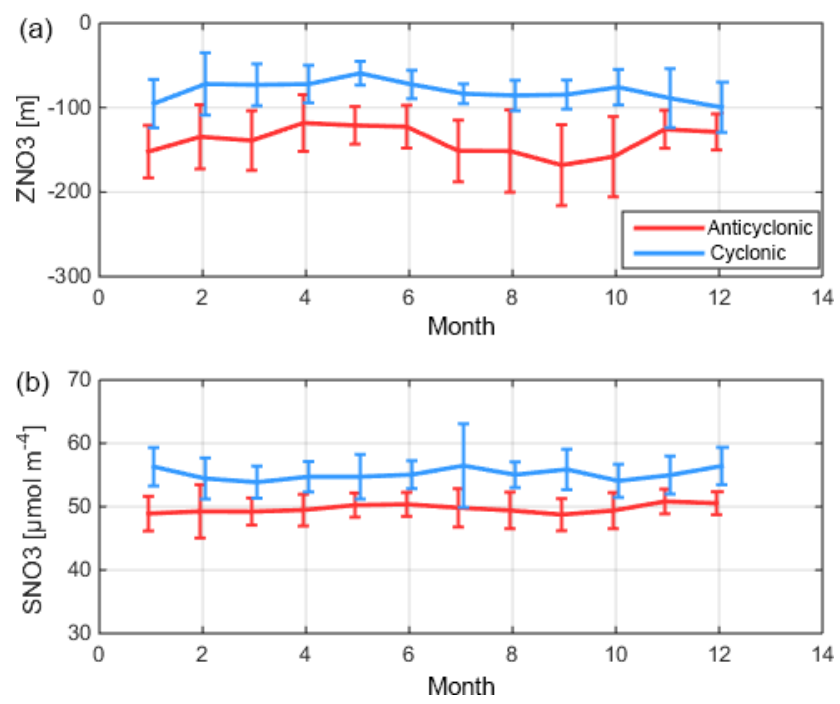

Figure 7. Basin-scale, monthly climatological mean and standard deviation of: (a) the nitracline depth, (b) the nitracline steepness. Red (blue) shows statistics for all profiles in anticyclonic (cyclonic) structures.

than its uptake by biota. Thus, apart from sporadic and rather localized events, it seems likely that large supplies of nutrients to the surface layer are not that common in winter in the GOM as a whole, since the basin-scale, monthly climatological averages of the MLD are shallower than the estimated depth of the nitracline. Note, however, that our results are limited by the temporal resolution of the floats' profiles (i.e., 14 days), as well as their uneven spatial distribution. This is particularly critical in winter, when the question of the biomass response to MLD deepening events is addressed. The variability in MLD and [CHL] tot (and also in $Z_{\mathrm{N}}$ ) deduced from bi-monthly profiles is likely underestimated, because mixing events are shorter than the temporal interval of the measurements. Our dataset only demonstrates that a $[\mathrm{CHL}]_{\text {tot }}$ increase in winter could be exclusively observed in specific areas and/or episodically (i.e., when the MLD is very deep and reaches the nitracline), and that such events do not contribute noticeably to the basin-scale monthly climatological averages.

\subsubsection{Nutrient vertical distribution in cyclones and anticyclones}

Float data also showed that the mesoscale activity is a main source of variability for the [CHL] field in the deep water GOM. In particular, a higher chlorophyll concentration was measured in cyclones with respect to anticyclones (Fig. 5). Figure 7 indicates that the [NN] distribution is also potentially modulated by the presence of mesoscale structures. Thus, $Z_{\mathrm{N}}$ is significantly shallower in cyclonic than in anticyclonic structures $(p<0.05)$, around $80 \mathrm{~m}$ in CG and $140 \mathrm{~m}$ in AG. This result is consistent with a shallower and inten- 


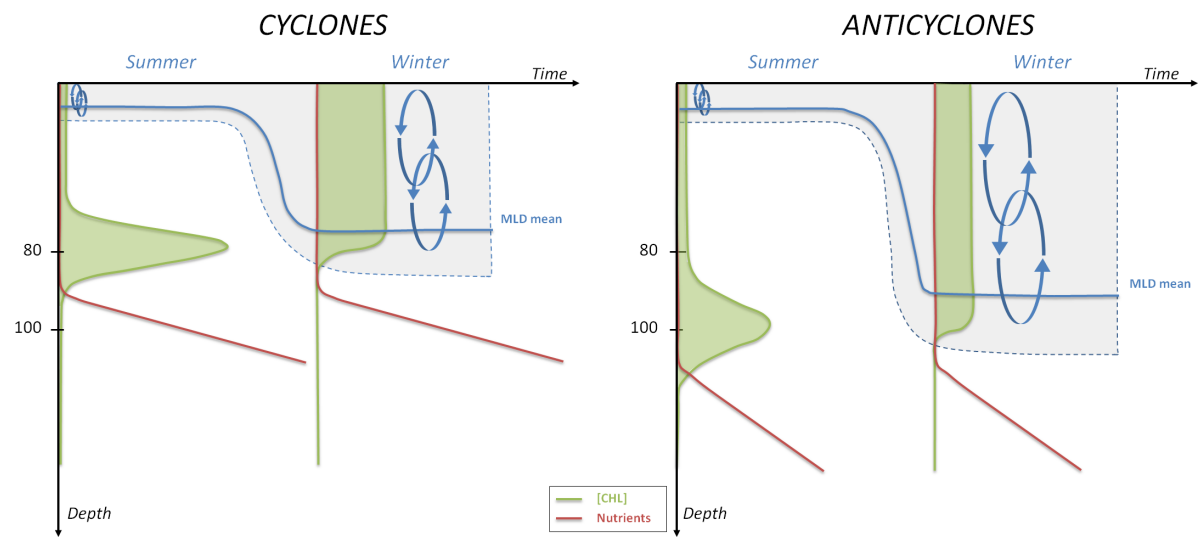

Figure 8. Conceptual view summarizing the basin-scale seasonal changes in the vertical distribution of chlorophyll (green), nutrients (red), mixed layer (shaded gray area), and mean mixed-layer depth (blue), in cyclones and anticyclones. The total chlorophyll content is represented by the green area, which is approximately the same in summer and winter for either cyclones or anticyclones. By contrast, the chlorophyll content in cyclones is larger than in anticyclones for either season, showing that cyclones have slightly higher biomass. This may be the result of slightly higher nutrient supply in cyclones due to a steeper nutricline, and hence a higher diffusive flux. Finally, note that the mixed layer does not on average reach the nutricline in winter, but it does reach the deep chlorophyll maximum, resulting in the vertical redistribution of chlorophyll via vertical mixing and/or photoacclimation processes.

sified DCM in CG than in AG, and in agreement with the conventional view, namely an upward doming of isopycnal surfaces accompanied by a shallowing of the nutricline and an elevated biomass in cyclones (McGillicuddy and Robinson, 1997; McGillicuddy et al., 1998; Oschlies and Garcon, 1998). However, understanding the factors that favor and maintain an enhanced biomass in cyclones is still debated, and the literature addresses a range of processes (see McGillicuddy, 2016, for a review). Our approach allows us to explore at least one mechanism: the role of the vertical flux of $[\mathrm{NN}]$ from below, via vertical diffusion. This flux is generally considered proportional to the nitrate vertical gradient $\left(S_{\mathrm{N}}\right)$ through the relationship $F_{\mathrm{N}}=K_{z} \cdot S_{\mathrm{N}}$ (with $K_{z}$ the diffusion coefficient; Okubo, 1971). The latest estimate of $K_{z}$ for the interior GOM is $0.15 \times 10^{-4} \mathrm{~m}^{2} \mathrm{~s}^{-1}$ (Ledwell et al., 2016), which is similar to what is observed in the open ocean (e.g., Ledwell et al., 1998). Thus, considering $K_{z}$ constant, a steeper nitracline in CG $(p<0.05$, Fig. 7$)$ suggests a higher upward diffusive flux in cyclones with respect to anticyclones. Mean $F_{\mathrm{N}}$ in $\mathrm{CG}$ and $\mathrm{AG}$ were estimated to be around 26 and $23 \mathrm{mmol} \mathrm{m}^{-2} \mathrm{yr}^{-1}$, respectively. As a consequence, the new primary production (based on the vertical diffusive flux of NN through the pycnocline) would also be higher in CG than in the AG. This higher new primary production could thus be a factor contributing to the observed enhanced [CHL] and biomass in cyclones, as already suggested by previous studies (Biggs et al., 1988; Biggs, 1992; Biggs and Müller-Karger, 1994; Yoder and Mahood, 1983; Zimmerman and Biggs, 1999), although it is difficult to assess with our database. Regenerated production, local regeneration (Belabbassi et al., 2005), and grazing (Banse, 1995) may also have a fundamental influence, but the answer to this question requires other measurements that are not at our disposal (e.g., oxygen).

\section{Summary and conclusions}

The use of profiling floats equipped with biogeochemical sensors provide continuous vertical profile data over wide areas that cannot be obtained otherwise at reasonable cost. The recent deployment of such platforms in the Gulf of Mexico (GOM) generated a remarkable and unique dataset, which covers a 5-year period. It allowed us to study the variability in phytoplankton biomass using in situ bio-optical data across the region, at a spatio-temporal resolution not reported before. Measurements provided information about the seasonal cycle at the surface and at depth, allowing us to study the influence of physical processes on the deep chlorophyll maximum (DCM), and the identification of the GOM as an oligotrophic system (see Fig. 8 for a conceptual view).

1. The surface chlorophyll ([CHL $]_{\text {surf }}$ ) annual pattern viewed by satellite is confirmed, and mixed-layer dynamics appears to be the main factor controlling this cycle.

2. When considering the integral content of chlorophyll $\left([\mathrm{CHL}]_{\text {tot }}\right)$, no seasonal variability is observed.

3. $[\mathrm{CHL}]_{\text {tot }}$ combined with the analysis of backscattering (bbp) data suggest that the total phytoplankton biomass is relatively constant at an annual scale, and that the winter increase in $[\mathrm{CHL}]_{\text {surf }}$ is primarily associated with a vertical redistribution of chlorophyll and/or photoacclimation processes, rather than a true biomass increase (Fig. 8). 
4. In addition, our observations show that the winter mixed layer is generally not deep enough to reach the nitracline. The sampling, however, only allows us to reach conclusions in a broad sense. Therefore, we suggest that, on a climatological basin-scale average, a relatively small amount of nutrients are potentially injected to the surface layer through vertical mixing. This does not discard the fact that at short timescales (days to weeks), events may result in high nutrient inputs to the photic layer, which translate into a local phytoplankton bloom, particularly during winter storms. Our interpretation is that the net effect of those blooms is not big enough to determine the basin-scale averages of surface chlorophyll content, hence nutrient supply by winter mixing is not necessarily the main cause of the seasonal, basin-scale variability of surface chlorophyll content.

5. Float profiles also reveal the subsurface CHL dynamics which cannot be determined by satellite observations. The temporal variability of the DCM appears coherent with isopycnal vertical excursions, and a shallower and intensified DCM is found in cyclonic-like structures (Fig. 8) - i.e., when isopycnals are uplifted.

6. The subsurface [CHL] increase in cyclones is also accompanied by a noticeable bbp increase, supporting that phytoplankton biomass is higher than in anticyclones. A potential but not conclusive explanation is a higher nutrient diffusive flux in cyclones that could contribute to strengthen the new primary production. This suggests that, at the annual scale, the impact of mesoscale features on the phytoplankton biomass may be more important than seasonal processes.

7. This analysis mainly considered the ecosystem from a "bottom-up" perspective, and we focus mostly on resources regulating phytoplankton growth (light and nutrients), rather than factors influencing losses (grazing, mortality). Other processes, such as submesoscale features (Klein and Lapeyre, 2009) or river run-off (Lohrenz et al., 1997), were not addressed in this study, although they could potentially impact the [CHL] distribution, particularly at shorter spatio-timescales than the ones analyzed in this study (Jochens and DiMarco, 2008).

8. Further deployments of bio-optical profiling floats in the GOM equipped with other biogeochemical sensors, such as nitrate (Johnson and Coletti, 2002; Pasqueron de Fommervault et al., 2015) or oxygen (Körtzinger et al., 2004; Riser and Johnson, 2008), and an increase in the temporal resolution of the profiles would significantly improve our understanding of the mechanisms controlling biomass variability and primary production in the GOM.
9. Another realistic alternative lies in the use of coupled biochemical/physical models to take advantage of the comprehensive 4-D vision they provide in terms of physics, nutrient dynamics, and simulated biological processes. However, at this time, the realism of numerical tools still needs to be improved in the GOM. The major barrier to this is the lack of in situ observations over the water column (specifically in deep waters), which remain essential for model validation (Walsh et al., 1989). This valuable dataset has recently been used to calibrate a coupled biochemical/physical model (NEMO-PISCES) and to evaluate its performances in the GOM (Damien et al., 2017). The model results are consistent with the hypothesis stated in this work, but also highlight that the BOEM floats' sampling scheme is unable to resolve all the scales of temporal and spatial variability.

Data availability. Profiling float data are available at the $\mathrm{Na}$ tional Oceanographic Data Center (NOAA), https://data.nodc.noaa. gov/cgi-bin/iso?id=gov.noaa.nodc:159562 (Hamilton and Leidos, 2017).

\section{The Supplement related to this article is available online at https://doi.org/10.5194/bg-14-5647-2017-supplement.}

Competing interests. The authors declare that they have no conflict of interest.

Acknowledgements. The APEX floats were part of the "Lagrangian Study of the Deep Circulation in the Gulf of Mexico", funded by the Bureau of Ocean and Energy Management, USA. Data acquisition and preprocessing thanks to Heather Furey, Theresa K. McKee, and Andree L. Ramsey (Woods Hole Oceanographic Institution). Nutrient data were measured during the XIXIMI-2 and XIXIMI-3 cruises, funded by INECC-SEMARNAT, FOINS-CONACYT, Mexico. Orens Pasqueron de Fommervault acknowledges a postdoctoral scholarship from CICESE, funded via a grant of the National Council of Science and Technology of Mexico Secretariat of Energy - Hidrocarbons Trust, project 201441. This is a contribution of the Gulf of Mexico Research Consortium (CIGoM).

Edited by: Emilio Marañón

Reviewed by: two anonymous referees

\section{References}

Antoine, D., Siegel, D. A., Kostadinov, T., Maritorena, S., Nelson, N. B., Gentili, B., Vellucci, V., and Guillocheau, N.: Variability in 
optical particle backscattering in contrasting bio-optical oceanic regimes, Limnol. Oceanogr., 56, 955-973, 2011.

Armstrong, F. A. J., Stearns, C. R., and Strickland, J. D. H.: The measurement of upwelling and subsequent biological process by means of the Technicon Autoanalyzer®and associated equipment, Deep-Sea Res., 14, 381-389, 1967.

Banse, K.: Zooplankton: Pivotal role in the control of ocean production I. Biomass and production, ICES J. Mar. Sci., 52, 265-277, 1995.

Behrenfeld, M. J. and Boss, E.: The beam attenuation to chlorophyll ratio: an optical index of phytoplankton physiology in the surface ocean? Deep-Sea Res. Pt. I, 50, 1537-1549, 2003.

Behrenfeld, M. J. and Boss, E.: Beam attenuation and chlorophyll concentration as alternative optical indices of phytoplankton biomass, J. Mar. Res., 64, 431-451, 2006.

Behrenfeld, M. J., Boss, E., Siegel, D. A., and Shea, D. M.: Carbon-based ocean productivity and phytoplankton physiology from space, Global Biogeochem. Cy., 19, 1006, https://doi.org/10.1029/2004GB002299, 2005.

Behrenfeld, M. J., O’Malley, R. T., Boss, E. S., Westberry, T. K., Graff, J. R., Halsey, K. H., Milligan, A. J., Siegel, D. A., and Brown, M. B.: Revaluating ocean warming impacts on global phytoplankton, Nat. Clim. Change, 6, 323-330, 2016.

Belabbassi, L., Chapman, P., Nowlin, W. D., Jochens, A. E., and Biggs, D. C.: Summertime nutrient supply to near-surface waters of the northeastern Gulf of Mexico: 1998, 1999, and 2000, Gulf of Mexico Science, 23, 137-160, 2005.

Biggs, D. C.: Nutrients, plankton, and productivity in a warm-core ring in the western Gulf of Mexico, J. Geophys. Res., 97, 21432154, 1992.

Biggs, D. C. and Müller-Karger, F. E.: Ship and satellite observations of chlorophyll stocks in interacting cyclone-anticyclone eddy pairs in the western Gulf of Mexico, J. Geophys. Res., 99, 7371-7384, 1994.

Biggs, D. C. and Ressler, P. H.: Distribution and abundance of phytoplankton, zooplankton, ichthyoplankton, and micronekton in the deepwater Gulf of Mexico, Gulf of Mexico Science, 19, 729, 2001.

Biggs, D., Wourmut, J., Mc Eachran, J., Brooks, D., and Kelly, F.: Multi-disciplinary study of Marn-and Cold core rings in the Gulf of Mexico, Congreso Iberoamericano y del Caribe, Punta de Piedras, Nueva Esparta, Venezuela, 8-15, 1988.

Boss, E., Swift, D., Taylor, L., Brickley, P., Zaneveld, R., Riser, S., Perry, M. J., and Strutton, P. G.: Observations of pigment and particle distributions in the western North Atlantic from an autonomous float and ocean color satellite, Limnol. Oceanogr., 53, 2112-2122, 2008.

Briggs, N., Perry, M. J., Cetinić, I., Lee, C., D’Asaro, E., Gray, A. M., and Rehm, E.: High-resolution observations of aggregate flux during a sub-polar North Atlantic spring bloom, Deep-Sea Res. Pt. I, 58, 1031-1039, 2011.

Bunge, L., Ochoa, J., Badan, A., Candela, J., and Sheinbaum, J.: Deep flows in the Yucatan Channel and their relation to changes in the Loop Current extension, J. Geophys. Res., 107, C12, https://doi.org/10.1029/2001JC001256, 2002.

Cullen, J. J.: The deep chlorophyll maximum: comparing vertical profiles of chlorophyll a, Can. J. Fish. Aquat. Sci., 39, 791-803, 1982.
Cullen, J. J. and Lewis, M. R.: Biological processes and optical measurements near the sea surface: Some issues relevant to remote sensing, J. Geophys. Res., 100, 13255-13266, 1995.

Cunningham, A., Cid, A., and Buma, A. G. J.: Variability of in-vivo chlorophyll fluorescence and its implication for instrument development in bio-optical oceanography, Sci. Mar., 60, 309-315, 1996.

Damien, P., Pasqueron de Fommervault, O., Sheinbaum, J., Jouanno, J., and Duteil, O.: Partitioning of the Gulf of Mexico based on the seasonal and interannual variability of chlorophyll concentration, J. Geophys. Res., in review, 2017.

de Boyer Montégut, C., Madec, G., Fischer, A. S., Lazar, A., and Iudicone, D.: Mixed layer depth over the global ocean: An examination of profile data and a profile-based climatology, J. Geophys. Res., 109, C12, https://doi.org/10.1029/2004JC002378, 2004.

Donohue, K., Hamilton, P., Leaman, K. Leben, R., Prater, M., Waddell, E., and Watts, R.: Exploratory Study of Deepwater Currents in the Gulf of Mexico, Vol. I: Executive Summary and Vol. II: Technical Report, OCS Study MMS 2006-073, 2006-074, 2007.

Donohue, K., Hamilton, P., Leben, R., Watts R., and Waddell, E.: Study of Deepwater Currents in the Northwestern Gulf of Mexico,Vol. I: Executive Summary and Vol II: Technical Report, OCS Study MMS 2008-030 and 2008-031 Volume I, 73 pp. and Volume II, 375 pp., 2008.

Dufois, F., Hardman-Mountford, N. J., Greenwood, J., Richardson, A. J., Feng, M., Herbette, S. J., and Matear, R.: Impact of eddies on surface chlorophyll in the South Indian Ocean, J. Geophys. Res., 119, 8061-8077, 2014.

Elliott, B. A.: Anticyclonic rings in the Gulf of Mexico, J. Phys. Oceanogr., 12, 1292-1309, 1982.

El-Sayed, S. Z.: Primary productivity and standing crop of phytoplankton, in: Chemistry, primary productivity, and benthic algae of the Gulf of Mexico, edited by: Bushnell, V. C., 8-13 pp., Americain Geographical Society, New York, 1972.

Falkowski, P. and Kiefer, D. A.: Chlorophyll a fluorescence in phytoplankton: relationship to photosynthesis and biomass, J. Plankton Res., 7, 715-731, 1985.

Fennel, K. and Boss, E.: Subsurface maxima of phytoplankton and chlorophyll: steady state solutions from a simple model, Limnol. Oceanogr., 48, 1521-1534, 2003.

Fennel, K., Hetland, R., Feng, Y., and DiMarco, S.: A coupled physical-biological model of the Northern Gulf of Mexico shelf: model description, validation and analysis of phytoplankton variability, Biogeosciences, 8, 1881-1899, https://doi.org/10.5194/bg-8-1881-2011, 2011.

Gaube, P., McGillicuddy, D. J., Chelton, D. B., Behrenfeld, M. J., and Strutton, P. G.: Regional variations in the influence of mesoscale eddies on near-surface chlorophyll, J. Geophys. Res., 119, 8195-8220, 2014.

Geider, R. J.: Light and temperature dependence of the carbon to chlorophyll a ratio in microalgae and cyanobacteria: implications for physiology and growth of phytoplankton, New Phytol., 106, 1-34, 1987.

Gordon, L. I., Jennings Jr., J. C., Ross, A. A., and Krest, J. M.: A suggested protocol for continuous flow automated analysis of seawater nutrients (phosphate, nitrate, nitrite and silicic acid) in the WOCE Hydrographic Program and the Joint Global Ocean Fluxes Study, WOCE Operations Manual, Part, 3, 3, 91-1, 1993. 
Green, R. E., Bower, A. S., and Lugo-Fernández, A.: First autonomous bio-optical profiling float in the Gulf of Mexico reveals dynamic biogeochemistry in deep waters, PloS one, 9, e101658, https://doi.org/10.1371/journal.pone.0101658, 2014.

Guinet, C., Xing, X., Walker, E., Monestiez, P., Marchand, S., Picard, B., Jaud, T., Authier, M., Cotté, C., Dragon, A. C., Diamond, E., Antoine, D., Lovell, P., Blain, S., D’Ortenzio, F., and Claustre, H.: Calibration procedures and first dataset of Southern Ocean chlorophyll a profiles collected by elephant seals equipped with a newly developed CTD-fluorescence tags, Earth Syst. Sci. Data, 5, 15-29, https://doi.org/10.5194/essd-5-15-2013, 2013.

Halsey, K. H. and Jones, B. M.: Phytoplankton strategies for photosynthetic energy allocation, Annu. Rev. Mar. Sci., 7, 265-297, 2015.

Hamilton, P.: Eddy statistics from Lagrangian drifters and hydrography for the northern Gulf of Mexico slope, J. Geophys. Res., 112, C9, https://doi.org/10.1029/2006JC003988, 2007a.

Hamilton, P.: Deep-Current Variability near the Sigsbee Escarpment in the Gulf of Mexico, J. Phys. Oceanogr, 37, 708-726, https://doi.org/10.1175/JPO2998.1, 2007b.

Hamilton, P. and Lee, T. N.: Eddies and Jets Over the Slope of the Northeast Gulf of Mexico, in: Circulation in the Gulf of Mexico: Observations and Models, edited by: Sturges, W. and LugoFernandez, A., American Geophysical Union, Washington, D.C., https://doi.org/10.1029/161GM010, 2005.

Hamilton, P. and Leidos: Ocean currents, temperatures, and others measured by drifters and profiling floats for the Lagrangian Approach to Study the Gulf of Mexico Deep Circulation project 2011-07 to 2015-06 (NCEI Accession 0159562), Version 1.1, NOAA National Centers for Environmental Information, Dataset, available at: https://data.nodc.noaa.gov/cgi-bin/iso?id= gov.noaa.nodc:159562, last access: 12 December 2017.

Hamilton, P., Berger, T. J., and Johnson, W.: On the structure and motions of cyclones in the northern Gulf of Mexico, J. Geophys. Res., 107, C12, https://doi.org/10.1029/1999JC000270, 2002.

Hamilton, P., Bower, A., Furey, H., Leben, R. R., and PérezBrunius, P.: Deep Circulation in the Gulf of Mexico: A Lagrangian Study, U.S. Dept. of the Interior, Bureau of Ocean Energy Management, Gulf of Mexico OCS Region, New Orleans, LA, OCS Study BOEM 20166081, 289 pp., available at: https://www.boem.gov/ESPIS/5/5583.pdf (last access: September 2017), 2016a.

Hamilton, P., Lugo-Fernández, A., and Sheinbaum, J.: A Loop Current experiment: Field and remote measurements, Dynam. Atmos. Oceans, 76, 156-173, 2016b.

Heileman, S. and Rabalais, N.: XV-50 Gulf of Mexico: LME\# 5. The UNEP Large Marine Ecosystem Report. A perspective on the changing condition in LMEs of the world's Regional Seas, United Nations Environment Programme, Nairobi, Kenya, UNEP Regional Seas Report and Studies, 182, 637-688, 2009.

Huot, Y., Morel, A., Twardowski, M. S., Stramski, D., and Reynolds, R. A.: Particle optical backscattering along a chlorophyll gradient in the upper layer of the eastern South Pacific Ocean, Biogeosciences, 5, 495-507, https://doi.org/10.5194/bg5-495-2008, 2008.

Jakobsen, H. H. and Markager, S.: Carbon-to-chlorophyll ratio for phytoplankton in temperate coastal waters: Seasonal patterns and relationship to nutrients, Limnol. Oceanogr., 61, 1853-1868, 2016.
Jochens, A. E. and DiMarco, S. F.: Physical oceanographic conditions in the deepwater Gulf of Mexico in summer 2000-2002, Deep-Sea Res. Pt. II, 55, 2541-2554, 2008.

Johnson, K. S. and Coletti, L. J.: In situ ultraviolet spectrophotometry for high resolution and long-term monitoring of nitrate, bromide and bisulfide in the ocean, Deep-Sea Res. Pt. I, 49, 12911305, 2002.

Johnson, K. S., Berelson, W. M., Boss, E., Chase, Z., Claustre, H., Emerson, S. R., Gruber, N., Körtzinger, A., Perry, M. J., and Riser, S. C.: Observing biogeochemical cycles at global scales with profiling floats and gliders prospects for a global array, Oceanography, 22, 216-225, 2009.

Jolliff, J. K., Kindle, J. C., Penta, B., Helber, R., Lee, Z., Shulman, I., Arnone, R., and Rowley, C. D.: On the relationship between satellite-estimated bio-optical and thermal properties in the Gulf of Mexico, J. Geophys. Res., 113, G1, https://doi.org/10.1029/2006JG000373, 2008.

Jouanno, J., Ochoa, J., Pallàs-Sanz, E., Sheinbaum, J., AndradeCanto, F., Candela, J., and Molines, J.-M.: Loop Current Frontal Eddies: Formation along the Campeche Bank and Impact of Coastally Trapped Waves, J. Phys. Oceanogr., 46, 3339-3363, https://doi.org/10.1175/JPO-D-16-0052.1, 2016.

Kamykowski, D. and Zentara, S. J.: Predicting plant nutrient concentrations from temperature and sigma-t in the upper kilometer of the world ocean, Deep-Sea Res. Pt. I, 33, 89-105, 1986.

Kiefer, D. A.: Chlorophyll a fluorescence in marine centric diatoms: responses of chloroplasts to light and nutrient stress, Mar. Biol., 23, 39-46, 1973.

Kitchen, J. and Zaneveld, J. R.: On the noncorrelation of the vertical structure of light scattering and chlorophyll-a in case I waters, J. Geophys. Res., 95, 20237-20246, 1990.

Klein, P. and Lapeyre, G.: The oceanic vertical pump induced by mesoscale and submesoscale turbulence, Annu. Rev. Mar. Sci., 1, 351-375, 2009.

Körtzinger, A., Schimanski, J., Send, U., and Wallace, D.: The ocean takes a deep breath, Science, 306, 1337-1337, 2004.

Koblenz-Mishke, O. J., Volkovinsky, V. K., and Kabanova, J. C.: Plankton primary production of the world ocean, in: Scientific Exploration of the south pacific, edited by: Wooster, W. W., pp. 183-193, National Academy of Science, Washington, DC, 1970.

Kouketsu, S., Tomita, H., Oka, E., Hosoda, S., Kobayashi, T., and Sato, K.: The role of meso-scale eddies in mixed layer deepening and mode water formation in the western North Pacific, J. Oceanogr., 68, 63-77, 2012.

Lavigne, H., D’Ortenzio, F., Claustre, H., and Poteau, A.: Towards a merged satellite and in situ fluorescence ocean chlorophyll product, Biogeosciences, 9, 2111-2125, https://doi.org/10.5194/bg9-2111-2012, 2012.

Leben, R. R. and Born, G. H.: Tracking Loop Current eddies with satellite altimetry, Adv. Space Res., 13, 325-333, 1993.

Ledwell, J. R., He, R., Xue, Z., DiMarco, S. F., Spencer, L. J., and Chapman, P.: Dispersion of a tracer in the deep Gulf of Mexico, J. Geophys. Res., 121, 1110-1132, https://doi.org/10.1002/2015JC011405, 2016.

Ledwell, J. R., Watson, A. J., and Law, C. S.: Mixing of a tracer in the pycnocline, J. Geophys. Res., 103, 21499-21529, 1998.

Linacre, L., Lara-Lara, R., Camacho-Ibar, V., Herguera, J. C., Bazán-Guzmán, C., and Ferreira-Bartrina, V.: Distribution pattern of picoplankton carbon biomass linked to mesoscale dy- 
namics in the southern Gulf of Mexico during winter conditions, Deep-Sea Res. Pt. I, 106, 55-67, 2015.

Lohrenz, S. E., Fahnenstiel, G. L., Redalje, D. G., Lang, G. A., Chen, X., and Dagg, M. J.: Variations in primary production of northern Gulf of Mexico continental shelf waters linked to nutrient inputs from the Mississippi River, Mar. Ecol.-Prog. Ser., 155, 45-54, 1997.

Loisel, H. and Morel, A.: Light scattering and chlorophyll concentration in case 1 waters: A reexamination, Limnol. Oceanogr., 43, 847-858, 1998.

Lorenzen, C. J.: A method for the continuous measurement of in vivo chlorophyll concentration, Deep-Sea Res., 13, 223-227, 1966.

Mann, K. H. and Lazier, J. R. N.: Dynamics of Marine Ecosystems: Biological-Physical Interactions in the Oceans, WileyBlackwell, Malden, Mass, 2006.

Mayot, N., D’Ortenzio, F., Taillandier, V., Prieur, L., Pasqueron de Fommervault, O., Claustre, H., Bosse, A., Testor, P., and Conan, P.: Physical and biogeochemical controls of the phytoplankton blooms in North-Western Mediterranean Sea: A multiplatform approach over a complete annual cycle (2012-2013 DEWEX experiment), J. Geophys. Res., accepted, https://doi.org/10.1002/2016JC012052, 2017.

McGillicuddy, D. J.: Mechanisms of physical-biologicalbiogeochemical interaction at the oceanic mesoscale, Annu. Rev. Mar. Sci., 8, 125-159, 2016.

McGillicuddy, D. J. and Robinson, A. R.: Eddy-induced nutrient supply and new production in the Sargasso Sea, Deep-Sea Res. Pt. I, 44, 1427-1450, 1997.

McGillicuddy, D. J., Robinson, A., Siegel, D., Jannasch, H., Johnson R., Dickey, T., McNeil, J., Michaels, A., and Knap, A.: Influence of mesoscale eddies on new production in the Sargasso Sea, Nature, 394, 263-266, 1998.

Melo González, N. M., Müller-Karger, F. E., Estrada, S. C., De Los Reyes, R. P., Del Rio, I. V., Pérez, P. C., and Arenal, I. M.: Nearsurface phytoplankton distribution in the western Intra-Americas Sea: The influence of El Nino and weather events, J. Geophys. Res., 105, 14029, https://doi.org/10.1029/2000JC900017, 2000.

Michaels, A. F. and Knap, A. H.: Overview of the U.S. JGOFS Bermuda Atlantic Time-series Study and the Hydrostation S program, Deep-Sea Res. Pt. II, 43, 157-198, https://doi.org/10.1016/0967-0645(96)00004-5, 1996.

Mignot, A., Claustre, H., D’Ortenzio, F., Xing, X., Poteau, A., and Ras, J.: From the shape of the vertical profile of in vivo fluorescence to Chlorophyll- $a$ concentration, Biogeosciences, 8, 23912406, https://doi.org/10.5194/bg-8-2391-2011, 2011.

Mignot, A., Claustre, H., Uitz, J., Poteau, A., D'Ortenzio, F., and Xing, X.: Understanding the seasonal dynamics of phytoplankton biomass and the deep chlorophyll maximum in oligotrophic environments: A Bio-Argo float investigation, Global Biogeochem. Cy., 28, 856-876, 2014.

Mitchell, B. G. and Kiefer, D. A.: Variability in pigment specific particulate fluorescence and absorption spectra in the northeastern Pacific Ocean, Deep-Sea Res. Pt. I, 35, 665-689, 1988.

Morel, A. and Maritorena, S.: Bio-optical properties of oceanic waters: a reappraisal, J. Geophys. Res., 106, 7163-7180, 2001.

Müller-Karger, F. E., Walsh, J. J., Evans, R. H., and Meyers, M. B.: On the seasonal phytoplankton concentration and sea surface temperature cycles of the Gulf of Mexico as determined by satellites, J. Geophys. Res., 96, 12645-12665, 1991.

Müller-Karger, F. E., Smith, J. P., Werner, S., Chen, R., Roffer, M., Liu, Y., Muhling, B., Lindo-Atichati, D., Lamkin J., CerdeiraEstrada, S., and Enfield, D. B.: Natural variability of surface oceanographic conditions in the offshore Gulf of Mexico, Prog. Oceanogr., 134, 54-76, 2015.

Nababan, B., Müller-Karger, F. E., Hu, C., and Biggs, D. C.: Chlorophyll variability in the northeastern gulf of mexico, Int. J. Remote Sens., 32, 8373-8391, 2011.

Nowlin, W. D. and McLellan, H. J.: A characterization of Gulf of Mexico waters in winter, J. Mar. Res., 25, 1292-1309, 1967.

Okubo, A.: Oceanic diffusion diagrams, Deep-Sea Res., 18, 789$802,1971$.

Omand, M. M. and Mahadevan, A.: The shape of the oceanic nitracline, Biogeosciences, 12, 3273-3287, https://doi.org/10.5194/bg-12-3273-2015, 2015.

Oschlies, A. and Garcon, V.: Eddy-induced enhancement of primary production in a model of the North Atlantic Ocean, Nature, 394, 266-269, 1998.

Pasqueron de Fommervault, O., D’Ortenzio, F., Mangin, A., Serra, R., Migon, C., Claustre, H., Lavigne, H., Ribera d'Alcala, M., Prieur, L., Taillandier, V., Schmechtig, C., Poteau, A., Leymarie, E., Dufour, A., Besson, F., and Obolensky, G.: Seasonal variability of nutrient concentrations in the Mediterranean Sea: Contribution of Bio-Argo floats, J. Geophys. Res., 120, 8528-8550, https://doi.org/10.1002/2015JC011103, 2015.

Penduff, T., Barnier, B., Dewar, W. K., and O'Brien, J. J.: Dynamical Response of the Oceanic Eddy Field to the North Atlantic Oscillation: A Model-Data Comparison, J. Phys. Oceanogr., 34, 2615-2629, https://doi.org/10.1175/JPO2618.1, 2004.

Qian, Y., Jochens, A. E., Kennicutt II, M. C., and Biggs, D. C.: Spatial and temporal variability of phytoplankton biomass and community structure over the continental margin of the northeast Gulf of Mexico based on pigment analysis, Cont. Shelf Res., 23, 1-17, 2003.

Riser, S. C. and Johnson, K. S.: Net production of oxygen in the subtropical ocean, Nature, 451, 323-325, 2008.

Roemmich, D. H., Davis, R. E., Riser, S. C., Owens, W. B., Molinari, R. L., Garzoli, S. L., and Johnson, G. C.: The argo project global ocean observations for understanding and prediction of climate variability, Scripps institution of oceanography, La Jolla, CA, 2003.

Salmerón-García, O., Zavala-Hidalgo, J., Mateos-Jasso, A., and Romero-Centeno, R.: Regionalization of the Gulf of Mexico from space-time chlorophyll-a concentration variability, Ocean Dyn., 61, 439-448, 2011.

Schmechtig, C., Claustre, H., Poteau, A., and D’Ortenzio, F.: BioArgo quality control manual for the Chlorophyll-A concentration, IFREMER, https://doi.org/10.13155/35385, 2014.

Schmitz, W. J.: Cyclones and Westward Propagation in the Shedding of Anticyclonic Rings from the Loop Current, in: Circulation in the Gulf of Mexico: Observations and Models, edited by: Sturges, W. and Lugo-Fernandez, A., American Geophysical Union, Washington, D.C., https://doi.org/10.1029/161GM18, 2005.

Sheinbaum, J., Badan, A., Ochoa. J., Candela, J., Rivas, D., and Gonzalez, J. I.: Full-Water Column Current Observations in the 
Central Gulf of Mexico, Final Report, OCS Study MMS 2007022, 2007.

Siegel, D. A., Behrenfeld, M.J., Maritorena, S., McClain, C. R., Antoine, D., Bailey, S. W., Bontempi P. S., Boss, E. S., Dierssen, H. M., Doney, S. C., Eplee Jr., R. E., Evans, R. H., Feldman, G. C., Fields, E., Franz, B. A., Kuring, N. A., Mengelt, C., Nelson, N. B., Patt, F. S., Robinson, W. D., Sarmiento, J. L., Swan, C. M., Werdell, P. J., Westberry, T. K., Wilding, J. G., and Yoder, J. A.: Regional to global assessments of phytoplankton dynamics from the SeaWiFS mission, Remote Sens. Environ., 135, 77-91, https://doi.org/10.1016/j.rse.2013.03.025, 2013.

Strickland, J. D. H.: Production of organic matter in the primary stages of the marine food chain, Chem. Oceanogr., 1, 477-610, 1965.

Sturges, W. and Leben, R.: Frequency of ring separations from the Loop Current in the Gulf of Mexico: A revised estimate, J. Phys. Oceanogr., 30, 1814-1819, 2000.

Toner, M., Kirwan, A. D., Poje, A. C., Kantha, L. H., Müller-Karger, F. E., and Jones, C. K. R. T.: Chlorophyll dispersal by eddy-eddy interactions in the Gulf of Mexico, J. Geophys. Res., 108, 3105, https://doi.org/10.1029/2002JC001499, 2003.

Uitz, J., Claustre, H., Morel, A., and Hooker, S. B.: Vertical distribution of phytoplankton communities in open ocean: An assessment based on surface chlorophyll, J. Geophys. Res., 111, C08005, https://doi.org/10.1029/2005JC003207, 2006.

Vidal, V., Vidal, F. V., and Pérez-Molero, J. M.: Collision of a Loop Current anticyclonic ring against the continental shelf slope of the western Gulf of Mexico, J. Geophys. Res., 97, 2155-2172, 1992.
Virmani, J. I. and Weisberg, R. H.: Features of the observed annual ocean-atmosphere flux variability on the west Florida shelf, J. Climate, 16, 734-745, 2003.

Walsh, J. J., Dieterle, D. A., Meyers, M. B., and Müller-Karger, F. E.: Nitrogen exchange at the continental margin: A numerical study of the Gulf of Mexico, Prog. Oceanogr., 23, 245-301, 1989.

Westberry, T. K., Dall'Olmo, G., Boss, E., Behrenfeld, M. J., and Moutin, T.: Coherence of particulate beam attenuation and backscattering coefficients in diverse open ocean environments, Opt. Express, 18, 15419-15425, 2010.

Xing, X., Claustre, H., Blain, S., D’Ortenzio, F., Antoine, D., Ras, J., and Guinet, C.: Quenching correction for in vivo chlorophyll fluorescence acquired by autonomous platforms: A case study with instrumented elephant seals in the Kerguelen region (Southern Ocean), Limnol. Oceanogr.-Meth., 10, 483-495, 2012.

Xue, Z., He, R., Fennel, K., Cai, W.-J., Lohrenz, S., and Hopkinson, C.: Modeling ocean circulation and biogeochemical variability in the Gulf of Mexico, Biogeosciences, 10, 7219-7234, https://doi.org/10.5194/bg-10-7219-2013, 2013.

Yoder, J. and Mahood, A.: Primary production in Loop Current upwelling, Woodward-Clyde Consultants/Skidaway Institute of Oceanography, Southwest Florida Shelf Ecosystems Study-Year, $2,1983$.

Zimmerman, R. A. and Biggs, D. C.: Patterns of distribution of sound-scattering zooplankton in warm- and cold-core eddies in the Gulf of Mexico, from a narrowband acoustic Doppler current profiler survey, J. Geophys. Res., 104, 5251-5262, 1999. 